\title{
Potency of Culled Saanen Crossbred Goat in Supplying Raw Meat for Traditional Thai Butchery
}

\author{
A. A. Putra ${ }^{\mathrm{a}, \mathrm{c}}$, S. Wattanachant $\mathrm{t}^{\mathrm{a}, *}$, \& C. Wattanachant ${ }^{\mathrm{b}}$ \\ aDepartment of Food Technology, Faculty of Agro-Industry, Prince of Songkla University, \\ Hat Yai, Songkhla, 90112, Thailand \\ bDepartment of Animal Science, Faculty of Natural Resources, Prince of Songkla University, \\ Hat Yai, Songkhla, 90112, Thailand \\ 'Division of Technology of Animal Products, Faculty of Animal Science, Universitas Andalas, \\ Limau Manis, Padang, 25163, Indonesia \\ (Received 07-03-2017; Reviewed 04-04-2017; Accepted 22-05-2017)
}

\begin{abstract}
Potency of culled Saanen crossbred goat meat to replace the supply of yearling Boer crossbred goat meat was evaluated. Selected muscles from leg and shoulder cuts were analysed for their nutritional (proximate composition, collagen, amino acids, fatty acids), physicochemical ( $\mathrm{pH}$, myoglobin, drip loss, cook loss, shear force, lightness $\left(\mathrm{L}^{*}\right)$ redness $\left(\mathrm{a}^{*}\right)$ yellowness $\left(\mathrm{b}^{*}\right)$, microstructure), and sensory (triangle test, hedonic test) evaluations. Meat samples from culled Saanen crossbred goat exhibited higher values in protein, collagen, and MUFA $(\mathrm{P}<0.05)$ than those from Boer crossbred goat, while lower values in ash, soluble collagen, and SFA were obtained $(\mathrm{P}<0.05)$. Meat from culled Saanen crossbred goat revealed higher cook loss, shear force, and redness compared to those from a yearling Boer crossbred goat $(P<0.05)$. In addition, thicker perimysium in meat of Saanen crossbred goat was obtained particularly that could be seen on leg part. In sensory evaluation result, the panels could detect the differences between raw meat characteristics of these goat breeds $(P<0.05)$ within the same muscle. However, the panels could not distinguish the difference between breeds in leg meat after being cooked. Shoulder meat of Saanen crossbred goat had less acceptance level compared to the other samples $(P<0.05)$ particularly on its texture and taste quality. In summary, shoulder cut of culled Saanen crossbred goat exhibited a well-intentioned potency to substitute the supply of meat from yearling Boer crossbred goat. Nevertheless, pre-treatment might be applied to leg cut of Saanen crossbred goat to solve the less acceptance level of its textural and taste characteristics.
\end{abstract}

Keywords: Saanen goat, Boer goat, goat meat quality, goat meat composition, microstructure of goat meat

\section{ABSTRAK}

Potensi daging kambing peranakan Saanen tua untuk mensubstitusi suplai daging kambing peranakan Boer telah dievaluasi. Otot dari bagian kaki dan bahu telah dianalisis untuk melihat kandungan nutrisi (komposisi proksimat, kolagen, asam amino, dan asam lemak), sifat fisikokimia ( $\mathrm{pH}$, mioglobin, susut drip, susut masak, shear force, lightness $\left(\mathbf{L}^{*}\right)$ redness $\left(\mathbf{a}^{*}\right)$ yellowness $\left(\mathbf{b}^{*}\right)$, dan mikrostruktur), dan penilaian sensori (uji segitiga dan uji hedonik). Berdasarkan penelitian didapatkan bahwa kandungan protein, kolagen, dan MUFA daging kambing peranakan Saanen lebih tinggi $(\mathbf{P}<0.05)$ daripada daging kambing peranakan Boer, sedangkan kadar abu, kolagen terlarut, dan SFA-nya lebih rendah $(P<0.05)$. Susut masak, shear force, dan redness daging kambing peranakan Saanen lebih tinggi daripada daging kambing peranakan Boer $(\mathrm{P}<0.05)$. Selain itu, gambaran perimisium yang lebih tebal $(\mathrm{P}<0.05)$ pada daging kambing peranakan Saanen telah didapatkan, terutama dapat dilihat pada bagian kaki. Pada penilaian sensori, panelis dapat membedakan daging mentah dari kedua bangsa kambing pada dua bagian karkas, tetapi panelis tidak dapat membedakan daging kaki di antara kedua bangsa kambing setelah dimasak. Daya terima panelis terhadap daging bahu paling rendah $(\mathrm{P}<0.05)$ dibandingkan sampel lainnya, terutama terkait dengan kualitas tekstur dan rasanya. Dapat disimpulkan bahwa daging bagian bahu kambing peranakan Saanen berpotensi sebagai alternatif pengganti daging kambing peranakan Boer. Sementara itu, daging bagian kaki kambing peranakan Saanen memerlukan perlakuan lanjutan untuk mengatasi daya terimanya yang rendah terkait sifat tekstur dan rasanya.

Kata kunci: kambing Saanen, kambing Boer, kualitas daging kambing, komposisi daging kambing, mikrostruktur daging kambing

${ }^{*}$ Corresponding author:

E-mail: saowakon.w@psu.ac.th 


\section{INTRODUCTION}

In Thailand, goat is an alternative livestock that is increasingly raised for meat and milk purposes. From statistics data, the number of goats increased about $23.2 \%$ from 380,277 heads in the year of 2010 to 468,377 heads in the year of 2014 (DLD, 2015). Goat rearing is popular in Thai-Muslim community (Anothaisinthawee et al., 2010; Seilsuth et al., 2016), particularly in Southern Thailand that shows an increasing rate of goat meat consumption (Jittapalapong et al., 2012). In general, goat reared traditionally under an extensive- or semi-intensive system using native goat breed supported with the availability of local feed sources.

Due to the lower performances of Thai native goat compared to the crossbred and pure bred goat (Supakorn et al., 2011; Anothaisinthawee et al., 2012), the Department of Livestock Development of Thailand imported several exotic breeds such as Boer, AngloNubian, Saannen to upgrade Thai goat breed. Thai crossbred goat obtained from native female Thai $x$ male Anglo-Nubian has been popularized since the last 30 years (Wasiksiri et al., 2013). Moreover, among various latest breeding programs now, Boer is one of the most accepted meat-type goat in Thailand, and is being a popular goat breed for goat meat butchery. This was due to the Boer and its crossbred goats performed better with a higher live weight gain and provided a better carcass yield than the other exotic crossbred or native goats (Anothaisinthawee et al., 2010; Anothaisinthawee et al., 2012).

From 2009 to present, the demand of goat meat was generally increased while the number of meat goat is not sufficient to slaughter for Thai goat meat consumption. Thus, to substitute the consumer needs, meat from dairy goat, particularly Saanen, is used to compensate the meat for the meat goat. Although Saanen is a popular dairy-type goat due to its higher milk yield (Mioč et al., 2007; Mioč et al., 2008), meat from Saanen both buck and culled doe are commonly supplied to the local butcher. However, meat from culled Saanen does might be less tender due to the older age, so the price is lower than meat from Boer meat goat. In fact, it should be highlighted that traditional consumers in the market pay an attention to the meat yield rather than the meat quality. Thus, it is needed to compare the quality of culled Saanen milking goat with Boer goat meat.

The objective of this study was to compare nutritional, physicochemical, and sensory attributes of meat between Saanen crossbred and Boer crossbred goats. Information obtained from this study would be benefit for consumers, butchers, producers, and researchers to see the possibility of culled Saanen does as an alternative for goat meat demand. In addition, it could also be a consideration to decide an appropriate pre-treatment for culled Saanen goat for meat products if it is needed. Moreover, some variations among various muscles within similar goat breed could be obtained. Thus, it was important to determine meat characteristics between selected muscles in leg and shoulder.

\section{MATERIALS AND METHODS}

\section{Materials}

Four 5-year-old Saanen crossbred (87.5\% Saanen $x \quad 12.5 \%$ Thai native; a main dairy breed reared in Thailand) and four 1-year-old Boer crossbred (75\% Boer $x$ 12.5\% Anglo-Nubian x 12.5\% Thai native; a main meat breed reared in Thailand) goats were obtained from Sitichai Dairy Goat Farm located in Sadao district, Songkhla, Thailand. Culled Saanen crossbred goats were raised under intensive system and were fed withchopped Napier grass (Pennisetum purpureum) ad libitum and concentrate was supplemented at $2.5 \%$ of body weight (14\% crude protein (CP) and $3.2 \mathrm{Mcal} / \mathrm{kg}$ ) to build up their body condition for about 3 months before being slaughtered. Boer crossbred goats were raised under a semi-intensive system when goats were kept in house and fed with chopped Napier grass ad libitum and concentrate diet (14\% CP and $3.2 \mathrm{Mcal} / \mathrm{kg}$ ) at $1.5 \%$ of body weight of each. Under a semi-intensive system, the experimental goats were allowed to graze on Ruzi grass (Brachiaria ruziziensis) paddock for about 3 to $4 \mathrm{~h}$ daily before being slaughtered.

The animals were transferred and slaughtered at Meat Laboratory, Department of Animal Science, Faculty of Natural Resources, Prince of Songkla University, Hat Yai District, Songkhla Province. The slaughtering procedure followed the guidelines enlightened in Thai Agricultural Standard 8400-2007 (National Bureau of Agricultural Commodity and Food Standards of Thailand, 2007) and Thai Agricultural Standard 9040-2013 (National Bureau of Agricultural Commodity and Food Standards of Thailand, 2013). After dressing the carcass using the skinning method, the carcass obtained was stored at $4^{\circ} \mathrm{C} / 18 \mathrm{~h}$ for aging. Then, meats from the leg cut (biceps femoris and semitendinosus) and the shoulder cut (supraspinatus and infraspinatus) were selected for analyses. Biceps femoris and supraspinatus representing samples used for physicochemical analyses and sensory evaluation, while semitendinosus and infraspinatus representing samples used for fatty acid profiles determination.

\section{Methods}

Proximate analysis. Proximate analysis was conducted based on the guidelines of the AOAC (2000). Moisture content was examined using oven drying, protein was measured using Kjeldahl, fat was investigated using soxhlet, and ash was obtained using dry ashing.

Total collagen. An acid hydrolysis method was applied to hydrolyse the protein from the sample as described by Palka (1999). $\mathrm{HCl} 6 \mathrm{~N}$ was used to hydrolyse $0.5 \mathrm{~g}$ minced sample using an oil bath $\left(110^{\circ} \mathrm{C}\right)$ for $24 \mathrm{~h}$. After reaching ambient temperature, an activated charcoal-clarification, filtration, neutralization, and distilled water-dilution were conducted. After that, hydroxyproline was determined following the method explained by Bergman \& Loxley (1963). The hydroxyproline content in sample was measured at the wavelength of $558 \mathrm{~nm}$ 
using a UV-spectrophotometer (UV-1700 PharmaSpec, Shimadzu Corporation, Japan). A-7.25 factor conversion was multiplied with hydroxyproline to convert the obtained diluted collagen into $\mathrm{mg} / \mathrm{g}$ meat sample.

Soluble collagen. The extraction of meat soluble collagen was prepared following the procedure explained by Liu et al. (1996). A total of $2 \mathrm{~g}$ minced meat was mixed with $25 \%$ Ringer solution using a homogenizer (WiggenHauser ${ }^{\circledR}$, Germany) for $1 \mathrm{~min}$. A heating procedure of the homogenate in a water bath at $77^{\circ} \mathrm{C}$ for $70 \mathrm{~min}$ was applied. Then, the centrifugation of heated homogenate at $2300 \mathrm{xg} / 30 \mathrm{~min} / 4^{\circ} \mathrm{C}$ was conducted. Supernatant obtained from centrifugal separation was collected. The precipitate was extracted again as the same procedure explained. After that, the latter obtained supernatant was combined with the former one. The hydrolysis procedure followed the same method as explained in total collagen hydrolysis. The result of soluble collagen was reported as a percentage of total collagen.

Fatty acid composition. Lipid extraction was prepared for fatty acid determination by following the method described by Bligh \& Dyer (1959). Then, the extracted lipids were esterified into fatty acid methyl esters (FAME) (Jham et al., 1982). After that, fatty acid methyl esters were determined using Gas Chromatograph, 7890 (Agilent Technologies, USA) based on Gas ChromatographyFlame Ionization Detector technique.

pH. pH determination was measured using the guidelines explained by Wattanachant et al. (2004). A total of $1 \mathrm{~g}$ sample was mixed with $25 \mathrm{~mL}$ deionized water using a homogenizer (WiggenHauser ${ }^{\circledR}$, Germany) for 1 min. A digital pH meter (SevenGo S62-FK2 Mettler Toledo, Switzerland) was used to measure the $\mathrm{pH}$ of the homogenate.

Myoglobin. An adapted method from Krzywicki (1982) was conducted to determine myoglobin content of the sample. The absorbance was determined at 572, 565, 545, and $525 \mathrm{~nm}$ using a UV-spectrophotometer (Libra S22 Biochrom, England). The total myoglobin content (Mmol/L) was calculated using the following formula:

Total myoglobin $=(-0.1666 \mathrm{R} 1+0.086 \mathrm{R} 2+0.088 \mathrm{R} 3+$ 0.099) $\times \mathrm{A}_{525}$

where R1, R2, and R3 are symbolised of A572/A525, A565/A525, and A545/A525, respectively.

A-16824 Da as molecular weight of goat myoglobin (Suman et al., 2009; Suman \& Joseph, 2013) was multiplied with the obtained myoglobin content to convert the result from $\mathrm{Mmol} / \mathrm{L}$ of diluted myoglobin into $\mathrm{mg} / \mathrm{g}$ of meat sample.

Drip loss and cook loss. Stainless steel surgical blade (Feather Safety Razor co ltd., Japan) was used for sizing meat sample into $2 \times 1 \times 0.5 \mathrm{~cm}$. For drip loss determination, the sample was blotted with multipurpose towel paper and weighed before being moved into a sealed plastic bag (size $4 \times 6 \mathrm{~cm}$ ). Then, the covered sample was stand on refrigerated temperature $\left(4^{\circ} \mathrm{C}\right)$ for $24 \mathrm{~h}$. After that, the sample was moved, blotted, and weighed again as was conducted in the initial preparation. Finally, drip loss was determined based on post weight and initial weight of sample measured and reported in percentage. For cook loss determination, sealed-plastic bag samples were heated on a water bath $\left(80^{\circ} \mathrm{C}\right)$ for $10 \mathrm{~min}$. After that, heated sample was cooled, blotted and weighed as performed on the beginning preparation. Calculation of cook loss was similar to that of drip loss (Wattanachant, 2005).

Texture. Sizing procedure of sample was conducted with the same protocol used for determinations of drip loss and cook loss. Texture of sample was determined using a texture analyser (TA-XTplus Stable Micro System Texture Analyser, UK). A-2 mm/s cross head speed and a-50 kg load cell was fixed on such instrument. Score obtained after a Warner-Bratzler blade cut the sample representing shear force of sample (Dawson et al., 1991).

Color. A Huntarlab colorimeter (Hunterlab ColorFlex, Virginia) was used to determine the color of sample. A black glass and a white standard tile were used to standardize the instrument before being applied for color measurement, respectively. Color was reported into lightness $\left(\mathrm{L}^{*}\right)$, redness $\left(\mathrm{a}^{*}\right)$, and yellowness $\left(\mathrm{b}^{*}\right)$ as used in International Commission on Illumination (CIE) system.

Microstructure. Microstructure determination was conducted using the method explained by Palka \& Daun (1999) with slight modification. A sizing procedure of meat into $1 \times 0.5 \times 0.5 \mathrm{~cm}$ was applied carefully using similar razor blade used in sample preparation for drip loss, cook loss, and texture analyses. The specimen was, then, fixed in $0.1 \mathrm{M}$ phosphate buffer $\mathrm{pH} 6.5$ containing $2.5 \%$ glutaraldehyde. After $2 \mathrm{~h}$ room temperature fixation, a rinsing procedure using distilled water was applied. Every $1 \mathrm{~h}$, then, a gradual dehydrated procedure using $25 \%, 50 \%, 70 \%, 95 \%$, and absolute ethanol of specimen were conducted. The latter procedure were applied twice. A nitrogen-short dipping procedure was conducted on specimen before a thin-cutting process using razor blade was performed. After the remaining of non solid substance was removed using critical point dryer (Polaron CPD7501, East Sussex, UK), the thin fragments were placed on an aluminium stubs and then a gold coating procedure was applied using sputter coater (West Chester, PA, USA). Then, the photograph of sample was taken using a SEM on $10 \mathrm{kV}$ accelerating voltage. A 500x (cross section) and a 10.000x (longitudinal section) magnification were used. Afterward, muscle fibre diameter and sarcomere length were determined using planimeter and vernier caliper, respectively. Fifteen measurements in each three video prints obtained were examined both for muscle fibre diameter and sarcomere length.

Sensory evaluation. Sensory evaluation was divided into triangle test and hedonic test following the general guidelines explained by Meilgaard et al. (2016). Thirty panels used both for triangle and hedonic test. Three digit numbers were used to code the samples served. In triangle test, the panels were served with one set of raw sample containing three meat pieces (two identical 
samples and one odd sample). The panel was asked to determine the odd sample. The determination of samples in triangle test was conducted for both raw leg and shoulder meat. In hedonic test, samples were prepared by cooking until reaching $80^{\circ} \mathrm{C}$ of end point temperature using boiling method. Then, the plain cooked samples were served to the panels. Nine-point-hedonic scale (1= dislike extremely, 9= like extremely) was applied to determine the preferences level for color, texture, taste, aroma, and overall acceptances.

Statistical analysis. This study was conducted using completely randomized design (CRD) for physicochemical analyses. The model of this design was $\mathrm{Yij}=\alpha+\tau_{\mathrm{j}}+\varepsilon_{\mathrm{ij}}$ where Yij was an observed value, $\alpha$ was an overall mean, $\tau$ was a fixed effect of treatment $i$, and $\varepsilon_{i j}$ was a random effect. In particular for sensory preference, randomized complete block design (RCBD) was applied through the following model: Yij $=\alpha+\beta_{i j}+\tau_{j}+\varepsilon_{i j^{\prime}}$ where Yij was an observed value, $\alpha$ was an overall mean, $\beta$ was a block effect or panel effect $i$, $\tau$ was a fixed effect of treatment $j$, and $\varepsilon_{i j}$ was a random effect. Statistical data analyses of physicochemical and sensory preferences were subjected to a one way ANOVA followed by Duncan's New Multiple Range Test using SPSS Statistics at 0.05 significant level. Significance in triangle test (0.05) was determined based on critical number (minimum) of correct answers as described by Meilgaard et al. (2016).

\section{RESULTS}

The result of nutritional composition and physicochemical characteristics of meat from yearling Boer and culled Saanen goats is presented in Table 1. Protein content of Saanen goat meat was considerably higher than that of Boer goat meat, while its intramuscular fat content exhibited a lower trend. Lower trend of fat content in Saanen meat compared to that of Boer meat was performed. Total collagen of meat from Saanen goat was higher than that of Boer goat within the same cut, while lower soluble collagen percentage of leg of Saanen goat meat was obtained. Saanen goat meat contained substantial lower saturated fatty acid (SFA) compared to Boer goat meat, while its monounsaturated fatty acids (MUFA) were higher. At the same time, polyunsaturated fatty acids (PUFA) of meat between breeds were not different.

$\mathrm{pH}$ of meat was varied between cuts, while meats from the leg cuts exhibited higher $\mathrm{pH}$ than those of the shoulders. Cook loss and shear force of Saanen goat meat were significantly higher than those of Boer goat meat, while its lightness was significantly lower. At the same time, the myoglobin content of the samples was not much different. The non-significant differences were obtained in the microstructure of samples both fibre diameter and sarcomere length. However, higher standard deviations in Saanen goat meat than those of Boer goat meat were obtained. Scanning electron micrographs of cross and longitudinal sections of muscles from culled Saanen crossbred and Boer crossbred goats are presented in Figure 1. From this Figure, it could be seen that fibre diameter among samples were not much different. Muscles structure of Saanen crossbred goat had thicker perimysium and endomysium compared to those of Boer crossbred goat, especially in leg perimysium. Moreover, smaller muscle fibre near the perimysium of meat from both breeds was obtained. At the same time, comparable sarcomere length in all samples were observed.

The results of sensory characteristics among goat meat samples were provided in Table 2. In triangle test, significant difference between breeds was found in raw leg, raw shoulder, and cooked leg samples, while no significance difference was obtained in cooked shoulder samples. In hedonic test, significant differences between breeds and muscle cuts were obtained for texture, taste, flavor, and overall acceptability. Moreover, texture and taste of leg meat from Saanen crossbred goat had the least acceptance level.

\section{DISCUSSION}

Higher protein contents obtained from Saanen samples related to the higher formation of collagen with the increasing age of the goat. The trend is similar with the result between dairy cattle $(22.39 \%)$ vs beef cattle $(20.85 \%)$ (Lizaso et al., 2011). It was noticed that dairy breed reached earlier maturity than beef breed (Wondifraw et al., 2013). Maturity level of animal breed determines collagen properties. Earlier mature animals were characterized by the higher collagen deposition (Jurie et al., 2007). Fat deposition between breeds is more associated with different locations of fat deposite. Visually, fat deposition of Saanen carcass could be seen in the form of adipose tissue in some areas between muscles as energy reserver rather than in intramuscular fat in the muscle. The phenomenon of the importance of adipose tissue as energy reserver in dairy breed was explained in Mishra et al. (2016).

Grain-concentrate feed provided for Saanen goat $(2.5 \% / d)$ was higher than that of Boer goat (1.5\%/day). In line with previous study, cattle finished on concentrate $(45.91 \%)$ presented a higher MUFA deposition compared to forage-finished (35.93\%) (Duckett et al., 2013). Grain-concentrate either commercial or self-manufactured by farmers was unsaturated-rich components. Deposition of unsaturated-rich components in muscle was responsible for this phenomenon.

The phenomenon occurred in $\mathrm{pH}$ might be related to the glycogen concentration. Glucose as a source of energy stored as glycogen is mostly in skeletal muscle (Ostrowska et al., 2015). Selected muscle in leg cut (biceps femoris) plays more activity movement during daily life, while selected muscle in shoulder cut (supraspinatus) attached near the bond and thus less active during animal movement. More active muscle used more glycogen concentration during daily activity. Thus, this condition lead to a less remaining of glycogen in leg cut could be converted to lactate to decrease the $\mathrm{pH}$.

The older the age as in culled Saanen, the longer the activity of animal and thus produce more myoglobin to bind oxygen to support the activity. At the same time, even though Boer were in yearling age, they have more activity due to their visits to paddock. Thus, 
Table 1. Nutritional composition and physicochemical characteristics of meat from culled Saanen crossbred and yearling Boer crossbred goats

\begin{tabular}{|c|c|c|c|c|}
\hline Parameter & Saanen leg & Saanen shoulder & Boer leg & Boer shoulder \\
\hline \multicolumn{5}{|l|}{ Proximate } \\
\hline Moisture (\%) & $77.01 \pm 0.99$ & $76.79 \pm 0.50$ & $76.90 \pm 0.89$ & $76.69 \pm 0.54$ \\
\hline Protein (\%) & $20.19 \pm 0.89^{a}$ & $19.40 \pm 0.97^{\mathrm{ab}}$ & $18.82 \pm 0.98^{\mathrm{ab}}$ & $18.54 \pm 0.53^{c}$ \\
\hline Fat $(\%)$ & $2.32 \pm 0.69^{\mathrm{b}}$ & $2.70 \pm 0.21^{\mathrm{ab}}$ & $2.63 \pm 0.44^{\mathrm{ab}}$ & $3.22 \pm 0.43^{\mathrm{a}}$ \\
\hline Ash (\%) & $1.05 \pm 0.01^{\mathrm{b}}$ & $1.08 \pm 0.02^{\mathrm{ab}}$ & $1.09 \pm 0.03^{\mathrm{a}}$ & $1.10 \pm 0.02^{\mathrm{a}}$ \\
\hline \multicolumn{5}{|l|}{ Collagen } \\
\hline Total collagen (mg/g) & $5.96 \pm 1.72^{\mathrm{a}}$ & $5.00 \pm 0.67^{\mathrm{ab}}$ & $3.06 \pm 0.74^{c}$ & $3.90 \pm 0.45^{\mathrm{bc}}$ \\
\hline Soluble collagen (\%) & $7.34 \pm 2.59^{b}$ & $11.36 \pm 4.92^{\mathrm{ab}}$ & $13.51 \pm 2.53^{\mathrm{a}}$ & $12.57 \pm 3.15^{\mathrm{ab}}$ \\
\hline \multicolumn{5}{|l|}{ Fatty acid (\% ratio) } \\
\hline C9:0 & ND & ND & ND & ND \\
\hline C10:0 & $0.06 \pm 0.02$ & $0.05 \pm 0.03$ & $0.24 \pm 0.27$ & $0.15 \pm 0.08$ \\
\hline $\mathrm{C} 11: 0$ & ND & ND & ND & ND \\
\hline $\mathrm{C} 12: 0$ & $0.20 \pm 0.08^{\mathrm{ab}}$ & $0.23 \pm 0.08^{\mathrm{a}}$ & $0.10 \pm 0.01^{\mathrm{c}}$ & $0.13 \pm 0.00^{\mathrm{bc}}$ \\
\hline C13:0 & $0.01 \pm 0.00$ & $0.04 \pm 0.08$ & $0.01 \pm 0.01$ & $0.01 \pm 0.01$ \\
\hline C14:0 & $2.59 \pm 0.45$ & $2.73 \pm 0.44$ & $2.10 \pm 0.31$ & $2.43 \pm 0.32$ \\
\hline C15:0 & $0.43 \pm 0.07$ & $0.43 \pm 0.08$ & $0.51 \pm 0.10$ & $0.57 \pm 0.12$ \\
\hline $\mathrm{C} 16: 0$ & $24.94 \pm 1.86^{\mathrm{ab}}$ & $26.26 \pm 1.12^{\mathrm{a}}$ & $22.77 \pm 0.68^{\mathrm{bc}}$ & $24.23 \pm 1.05^{\mathrm{c}}$ \\
\hline C16:1 & $3.63 \pm 0.33^{\mathrm{a}}$ & $3.30 \pm 0.72^{\mathrm{a}}$ & $2.11 \pm 0.31^{\mathrm{b}}$ & $1.70 \pm 0.91^{\mathrm{b}}$ \\
\hline $\mathrm{C} 17: 0$ & $1.06 \pm 0.20^{\mathrm{b}}$ & $1.04 \pm 0.12^{\mathrm{b}}$ & $1.51 \pm 0.24^{\mathrm{a}}$ & $1.48 \pm 0.29^{\mathrm{a}}$ \\
\hline C18:0 & $14.29 \pm 2.53^{b}$ & $14.44 \pm 1.99^{b}$ & $24.12 \pm 3.36^{a}$ & $23.83 \pm 3.34^{\mathrm{a}}$ \\
\hline C18:1 & $46.84 \pm 1.78^{\mathrm{a}}$ & $45.24 \pm 3.22^{\mathrm{ab}}$ & $39.65 \pm 3.97^{\mathrm{b}}$ & $40.80 \pm 4.69^{b}$ \\
\hline $\mathrm{C} 18: 2$ & $4.83 \pm 1.41$ & $5.34 \pm 2.68$ & $4.52 \pm 0.48$ & $2.84 \pm 2.00$ \\
\hline $\mathrm{C} 18: 3$ & $0.16 \pm 0.11^{b}$ & $0.23 \pm 0.02^{b}$ & $1.47 \pm 0.26^{\mathrm{a}}$ & $1.22 \pm 0.17^{a}$ \\
\hline C20:0 & $0.09 \pm 0.02$ & $0.04 \pm 0.06$ & $0.04 \pm 0.08$ & $0.07 \pm 0.27$ \\
\hline C20:1 & $0.26 \pm 0.07^{a}$ & $0.26 \pm 0.06^{\mathrm{a}}$ & $0.04 \pm 0.04^{b}$ & $0.04 \pm 0.04^{b}$ \\
\hline C22:0 & ND & ND & ND & ND \\
\hline C22:1 & ND & ND & ND & ND \\
\hline C24:0 & $0.40 \pm 0.27$ & $0.30 \pm 0.37$ & $0.46 \pm 0.47$ & $0.32 \pm 0.28$ \\
\hline C24:1 & ND & ND & ND & ND \\
\hline SFA & $44.11 \pm 1.77^{\mathrm{b}}$ & $45.60 \pm 2.51^{\mathrm{b}}$ & $52.01 \pm 4.74^{\mathrm{a}}$ & $53.27 \pm 5.06^{\mathrm{a}}$ \\
\hline MUFA & $50.91 \pm 1.98^{\mathrm{a}}$ & $48.83 \pm 3.88^{\mathrm{ab}}$ & $42.01 \pm 4.56^{\mathrm{b}}$ & $42.68 \pm 5.81^{\mathrm{b}}$ \\
\hline PUFA & $4.99 \pm 1.47^{a}$ & $5.57 \pm 2.69^{a}$ & $5.98 \pm 0.32^{\mathrm{a}}$ & $4.05 \pm 2.04^{\mathrm{a}}$ \\
\hline UFA & $55.89 \pm 1.76^{a}$ & $54.40 \pm 2.53^{\mathrm{a}}$ & $47.99 \pm 4.74^{\mathrm{b}}$ & $46.74 \pm 5.07^{\mathrm{b}}$ \\
\hline SFA/UFA & $0.79 \pm 0.05^{\mathrm{b}}$ & $0.84 \pm 0.08^{\mathrm{b}}$ & $1.10 \pm 0.20^{\mathrm{a}}$ & $1.16 \pm 0.23^{a}$ \\
\hline \multicolumn{5}{|l|}{ Physicochemical } \\
\hline $\mathrm{pH}$ & $6.04 \pm 0.15^{\mathrm{a}}$ & $5.76 \pm 0.08^{\mathrm{b}}$ & $6.23 \pm 0.32^{\mathrm{a}}$ & $5.86 \pm 0.14^{b}$ \\
\hline Myoglobin (mg/g) & $11.30 \pm 1.83^{\mathrm{a}}$ & $10.63 \pm 1.78^{\mathrm{a}}$ & $9.90 \pm 1.11^{\mathrm{a}}$ & $9.93 \pm 1.16^{\mathrm{a}}$ \\
\hline Drip loss (\%) & $1.60 \pm 0.20^{\mathrm{b}}$ & $2.21 \pm 0.60^{\mathrm{a}}$ & $1.60 \pm 0.35^{\mathrm{b}}$ & $1.53 \pm 0.15^{\mathrm{b}}$ \\
\hline Cook loss (\%) & $38.75 \pm 1.03^{\mathrm{a}}$ & $38.78 \pm 0.60^{\mathrm{a}}$ & $35.87 \pm 1.62^{\mathrm{b}}$ & $35.98 \pm 0.33^{b}$ \\
\hline Shear force & $4.64 \pm 0.45^{\mathrm{a}}$ & $4.34 \pm 0.37^{\mathrm{ab}}$ & $3.83 \pm 0.46^{\mathrm{bc}}$ & $3.50 \pm 0.38^{c}$ \\
\hline Lightness $\left(\mathrm{L}^{*}\right)$ & $33.12 \pm 0.96^{\mathrm{b}}$ & $34.44 \pm 0.90^{\mathrm{b}}$ & $39.85 \pm 1.16^{\mathrm{a}}$ & $40.88 \pm 1.73^{\mathrm{a}}$ \\
\hline Redness $\left(a^{*}\right)$ & $16.71 \pm 1.10^{\mathrm{a}}$ & $15.83 \pm 0.99^{\mathrm{ab}}$ & $15.08 \pm 0.82^{\mathrm{ab}}$ & $14.36 \pm 0.66^{\mathrm{b}}$ \\
\hline Yellowness $\left(b^{*}\right)$ & $12.18 \pm 1.22$ & $11.93 \pm 0.51$ & $10.36 \pm 2.75$ & $10.82 \pm 2.33$ \\
\hline Fibre diameter $(\mu \mathrm{m})$ & $32.51 \pm 3.07$ & $33.30 \pm 4.47$ & $30.23 \pm 1.50$ & $31.67 \pm 2.96$ \\
\hline Sarcomere length $(\mu \mathrm{m})$ & $1.42 \pm 0.19$ & $1.46 \pm 0.11$ & $1.31 \pm 0.14$ & $1.30 \pm 0.06$ \\
\hline
\end{tabular}

Note: Means in the same rows with different superscripts differ significantly $(\mathrm{P}<0.05)$. ND= not detected.

older age and limited movement of Saanen goat makes a balance condition toward younger age and higher movement of Boer goats. This phenomenon is similar with the age- (Kim et al., 2012) and activity-related fac- tors (Huuskonen et al., 2010) implied from the results of previous studies.

During heating, structure of collagen would be initially denatured and shrinkaged particularly on its peri- 
Saanen leg-MF

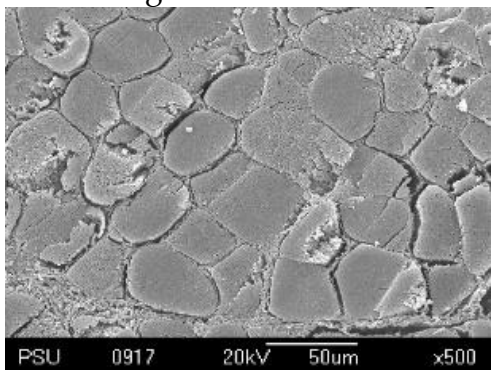

Saanen shoulder-MF

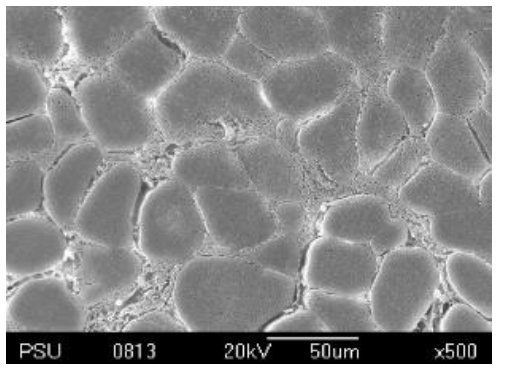

Boer leg-MF

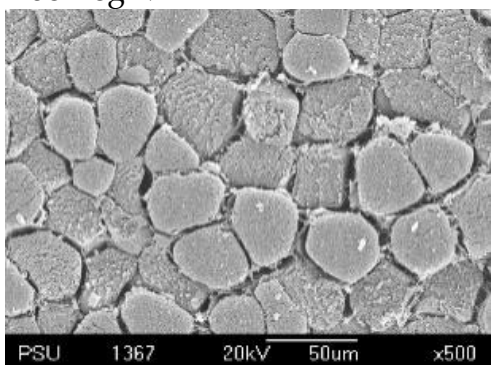

Boer shoulder-MF

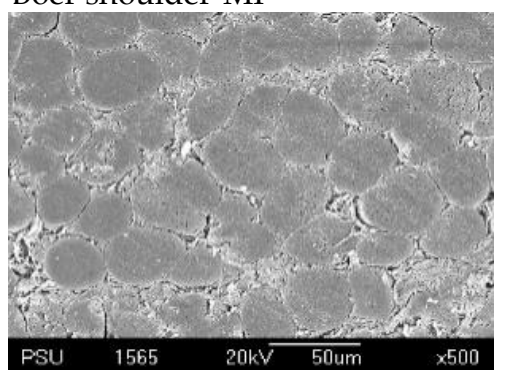

Saanen leg-IMCT

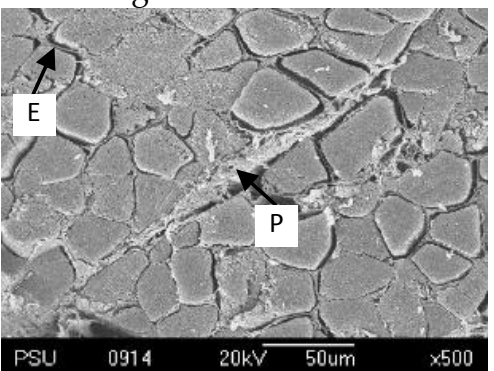

Saanen shoulder-IMCT

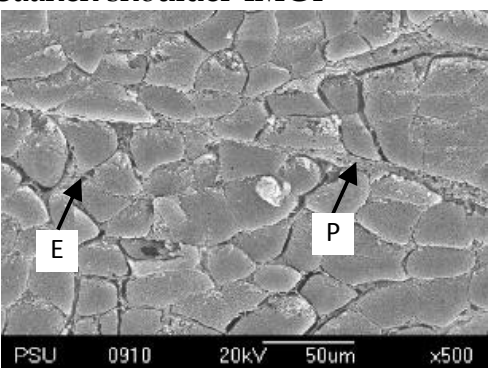

Boer leg-IMCT

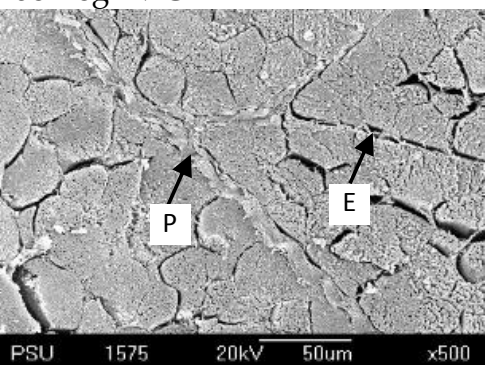

Boer shoulder-IMCT

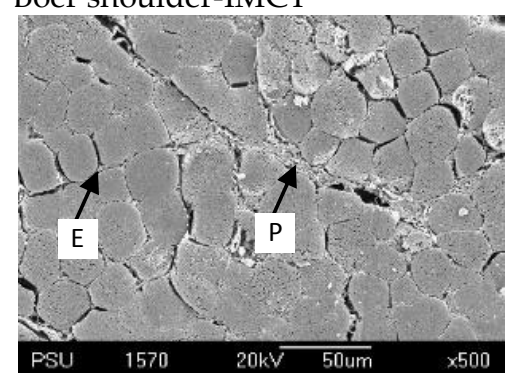

Saanen leg-S

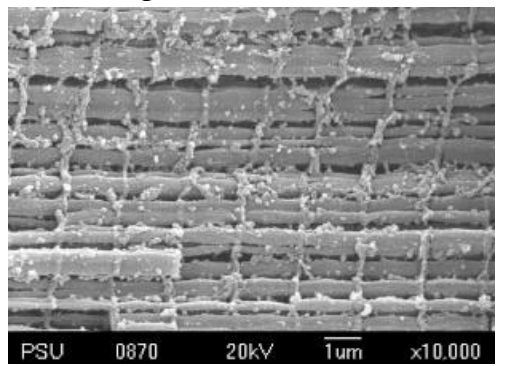

Saanen shoulder-S

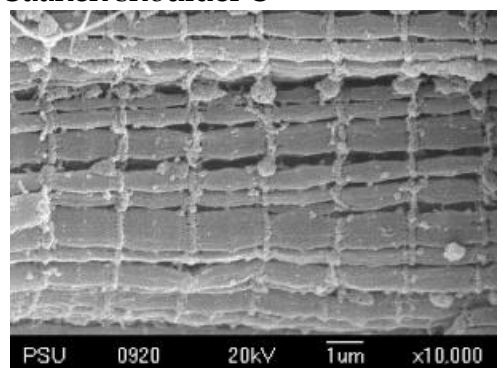

Boer leg-S

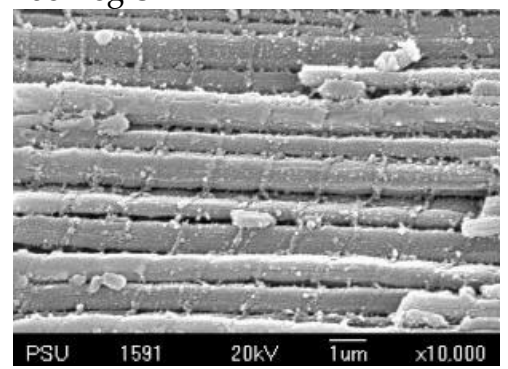

Boer shoulder-S

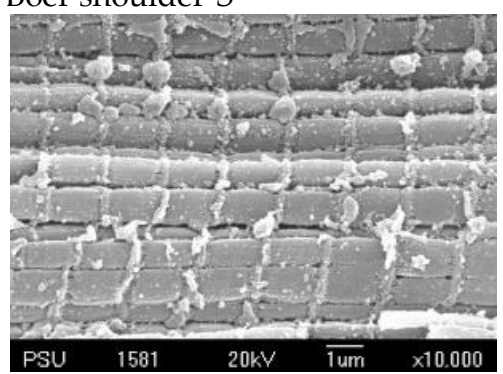

Figure 1. Scanning electron micrographs of cross and longitudinal sections of leg and shoulder from culled Saanen crossbred and yearling Boer crossbred goats. Note: $\mathrm{MF}=$ muscle fibre, $\mathrm{IMCT}=$ intramuscular connective tissue, $\mathrm{S}=$ sarcomere, $\mathrm{P}=$ perimysium, $\mathrm{E}=$ endomysium. _ with x500 magnification in muscle fibre (MF) and intramuscular connective tissue (IMCT) micrographs was equivalent to $50 \mu \mathrm{m}$, _ with x100.000 magnification in sarcomere (S) micrograph was equivalent to $1 \mu \mathrm{m}$.

Table 2. Sensory evaluation of meat from culled Saanen crossbred and yearling Boer crossbred goats

\begin{tabular}{|c|c|c|c|c|}
\hline \multirow[b]{2}{*}{ Triangle test } & \multicolumn{4}{|c|}{ Sensory evaluation } \\
\hline & Raw leg & Raw shoulder & Cooked leg & Cooked shoulder \\
\hline Significance & $\mathrm{P}<0.05$ & $\mathrm{P}<0.05$ & $\mathrm{P}<0.05$ & $\mathrm{P} \geq 0.05$ \\
\hline Hedonic test & Boer leg & Boer shoulder & Saanen leg & Saanen shoulder \\
\hline Color & $5.97 \pm 1.97$ & $6.57 \pm 1.74$ & $6.13 \pm 1.80$ & $6.23 \pm 1.48$ \\
\hline Texture & $5.83 \pm 1.84^{\mathrm{b}}$ & $6.93 \pm 1.72^{\mathrm{a}}$ & $4.57 \pm 2.03^{c}$ & $6.13 \pm 1.66^{\mathrm{ab}}$ \\
\hline Taste & $5.67 \pm 1.81^{b}$ & $6.53 \pm 1.28^{a}$ & $5.00 \pm 1.97 \mathrm{c}$ & $5.77 \pm 1.81^{b}$ \\
\hline Flavor & $5.77 \pm 1.85^{\mathrm{ab}}$ & $6.13 \pm 1.80^{\mathrm{a}}$ & $5.00 \pm 2.23^{c}$ & $5.77 \pm 1.68^{\mathrm{ab}}$ \\
\hline Overall acceptance & $5.83 \pm 1.64^{\mathrm{bc}}$ & $6.73 \pm 1.28^{\mathrm{a}}$ & $5.27 \pm 1.82^{c}$ & $6.07 \pm 1.48^{\mathrm{b}}$ \\
\hline
\end{tabular}

Note: Means in the same rows with different superscripts differ significantly $(\mathrm{P}<0.05)$ 
mysium and endomysium. Then, collagen solubilisation gradually occurred (Chang et al., 2011). As a result, some water progressively comes out from muscle fibre. Thus, a higher cook loss performed in Saanen goat might be related to its higher collagen content. It was also reliable that, to some degree, higher collagen percentage might be lowering myofibrillar protein percentage. Then, sample with less myofibrillar content was also going into limited ability to hold water.

A higher shear force found in Saanen goat meat was directly related to its collagen content. Besides, Saanen goat meat also had less soluble collagen percentage than that of Boer goat meat particularly on leg part. This represented that Saanen leg had a higher cross linking collagen, which lead to tougher texture. In addition, thicker perimysium in Boer leg (Figure 1) supports this phenomenon. A research reported by Ding et al. (2010) also found a higher shear force in the meat from dairy goat compared to that of its crossing with Boer goats.

A slightly higher trend in fat of Saanen samples might lead to a significant effect on lightness $\left(\mathrm{L}^{*}\right)$ as was also noticed in positive correlation of fatness-ligtness reported by Węglarz (2010). Other possible factor such as variation of oxidative stability of myoglobin (Adeyemi et al., 2016) might be also reliable to elucidate the higher difference in meat lightness.

Some muscle fibres in Saanen crossbred goat might be developed well and bigger as the effect of age, while some others had limited development resulted from less mobility and thus leading to a high variation of fibre diameter. At the same time, muscle fibre in the Boer crossbred goat developed in a better way by less variation size due to a routine activity in a wider area (paddock). As explained by Joo et al. (2013), total number and cross section area of fibre were related with its contractile function and fibre type composition. In addition, muscle structure of Saanen goat meat had thicker perimysium and endomysium, especially in leg perimysium.

Result in triangle test reflected that panels could detect difference of meat between breeds in both raw leg and shoulder samples. In brief, texture of sample resulted more effect in triangle test. At the same time, difference in cooked leg samples between Boer crossbred and Saanen crossbred meat also detectable. Lower soluble collagen percentage in Saanen leg representing a higher collagen crosslinking as also found in bulls as explained by Christensen et al. (2011). The more collagen crosslinking caused less collagen solubilization. Thus, the structure still tougher than Boer shoulder after being cooked. Similar collagen percentage between shoulder cuts of both breeds resulted comparable cooked condition. Less perimysium in meat of shoulder cut caused more heat energy to rupture meat structure during heating.

In hedonic score, texture and taste of leg meat from Saanen goat had the least acceptance level. This was due to the tougher texture intensity obtained from such sample. Besides, the higher trend of MUFA on leg meat might attribute to a more oxidation during cooking. The difference in fatty acid composition might be the most substantial factors to explain the triangle test result in leg cooked samples.

\section{CONCLUSION}

Meat from Saanen crossbred goat was healthier as related to its higher MUFA percentage. However, extra proper handling would be required since lipid oxidation was possibly prone to be oxidized in this sample. Tougher texture resulted in selected mucle in raw leg Saanen crossbred samples revealed the comparable occurrence after cooking as implied from the result in the triangle test. Shear force and fatty acids might contribute more impact to make a difference in sensory acceptance. Meat from selected muscles of shoulder cut of Saanen crossbred could be directly used to substitute Boer crossbred meat. However, the meat from selected muscles of leg cut of Saanen crossbred goat needed pretreatment before being cooked to solve its textural and taste challenging.

\section{ACKNOWLEDGEMENTS}

This research was funded by Prince of Songkla University of Area Based Research Grant number AGR581130S-0. First author acknowledged the scholarship provided by the Ministry of Research, Science and Technology of the Republic of Indonesia.

\section{REFERENCES}

Adeyemi, K. D., R. M. Shittu, A. B. Sabow, M. Ebrahimi, \& A. Q. Sazili. 2016. Influence of diet and post-mortem ageing on oxidative stability of lipids, myoglobin and myofibrillar proteins and quality attributes of gluteus medius muscle in goats. PLoS ONE. 11:1-15. https://doi.org/10.1371/journal.pone. 0154603

Anothaisinthawee, S., K. Nomura, T. Oishi, \& T. Amano. 2010. Goat genetic resources and breeding strategies in Thailand. J. Anim. Genet. 38:41-48. https://doi.org/10.5924/ abgri.38.41

Anothaisithawee, S., C. Wattanachant, K. Nomura, T. Oishi, \& T. Amano. 2012. Carcass and meat quality of three genotype populations in goat breeding for meat purposes in Thailand. J. Agr. Sci. 57:63-70.

AOAC. 2000. Official Methods of Analysis of AOAC International. 17thed. Association of Official Analytical Chemists (AOAC) International, Maryland.

Bergman, I., \& R. Loxley. 1963. Two improved simplified methods for the spectrophotometric determination of hydroxyproline. Anal. Chem. 35:1961-1965. https://doi.org/10.1021/ ac60205a053

Bligh, E. G., \& W. J. Dyer. 1959. A rapid method of total lipid extraction and purification. Can. J. Biochem. Physiol. 37:911-917. https://doi.org/10.1139/o59-099

Chang, H., Q. Wang, X. Xu, C. Li, M. Huang, G. Zhou, \& Y. Dai. 2011. Effect of heat-induced changes of connective tissue and collagen on meat texture properties of beef semitendinosus muscle. Int. J. Food Prop. 14:381-396. https://doi. org/10.1080/10942910903207728

Christensen, M., P. Ertbjerg, S. Failla, C. Sa-udo, R. I. Richardson, G. R. Nute, J. L. Olleta, B. Panea, P. Albertí, M. Juárez, J.-F. Hocquette, \& J. L. Williams. 2011. Relationship between collagen characteristics, lipid content and raw and cooked texture of meat from young bulls of fifteen European breeds. Meat Sci. 87:61-65. https://doi. org/10.1016/j.meatsci.2010.09.003

Dawson, P. L., B. W. Sheldon, \& J. J. Miles. 1991. Effect of aseptic processing on the texture of chicken meat. Poult. Sci. 
70:2359-2367. https://doi.org/10.3382/ps.0702359

Ding, W., L. Kou, B. Cao, \& Y. Wei. 2010. Meat quality parameters of descendants by grading hybridization of Boer goat and Guanzhong dairy goat. Meat Sci. 84:323-328. https:// doi.org/10.1016/j.meatsci.2009.04.015

DLD. 2015. Statistic of Goat in Thailand Year 2014. Department of Livestock Development (DLD), Ministry of Agriculture, Thailand. http://ict.dld.go.th/th2/index.php/th/report/196report-thailand-livestock/reportservey2557/700-reportsurvey57-1 [1May 1, 2015].

Duckett, S. K., J. P. S. Neel, R. M. Lewis, J. P. Fontenot, \& W. M. Clapham. 2013. Effects of forage species or concentrate finishing on animal performance, carcass and meat quality. J. Anim. Sci. 91:1454-1467. https://doi.org/10.2527/ jas.2012-5914

Huuskonen, A., E. Joki-Tokola, M. Honkavaara, L. Tuomisto, \& R. Kauppinen. 2010. Meat quality and fatty acid profile of M. longissimus dorsi of growing bulls under insulated, uninsulated and outdoor housing conditions. Agric. Food Sci.19:214-222.https://doi.org/10.2137/145960610792912620

Jham, G. N., F. F. F. Teles, \& L. G. Campos. 1982. Use of aqueous $\mathrm{HCl} / \mathrm{MeOH}$ as esterification reagent for analysis of fatty acids derived from soybean lipids. J. Am. Oil Chem. Soc. 59:132-133. https://doi.org/10.1007/BF02662261

Jittapalapong, S., S. Saengow, N. Pinyopanuwat, W. Chimnoi, W. Khachaeram, \& R. W. Stich. 2012. Gastrointestinal helminthic and protozoal infections of goats in Satun, Thailand. J. Trop. Med. Parasitol. 35:48-54.

Joo, S. T., G. D. Kim, Y. H. Hwang, \& Y. C. Ryu. 2013. Control of fresh meat quality through manipulation of muscle fiber characteristics. Meat Sci. 95:828-836. https://doi. org/10.1016/j.meatsci.2013.04.044

Jurie, C., B. Picard, J. -F. Hocquette, E. Dransfield, D. Micol, \& A. Listrat. 2007. Muscle and meat quality characteristics of Holstein and Salers cull cows. Meat Sci. 77:459-466. https:// doi.org/10.1016/j.meatsci.2007.04.014

Kim, Y. H. B., A. Stuart, C. Black, \& K. Rosenvold. 2012. Effect of lamb age and retail packaging types on the quality of long-term chilled lamb loins. Meat Sci. 90:962-966. https:// doi.org/10.1016/j.meatsci.2011.11.040

Krzywicki, K. 1982. The determination of haem pigments in meat. Meat Sci. 7:29-36. https://doi. org/10.1016/0309-1740(82)90095-X

Liu, A., T. Nishimura, \& K. Takahashi. 1996. Relationship between structural properties of intramuscular connective tissue and toughness of various chicken skeletal muscles. Meat Sci. 43:43-49. https://doi.org/10.1016/0309-1740(95)00065-8

Lizaso, G., M. J. Beriain, A. Horcada, J. Chasco, \& A. Purroy. 2011. Effect of intended purpose (dairy/beef production) on beef quality. Can. J. Anim. Sci. 91:97-102. https://doi. org/10.4141/CJAS10078

Meilgaard, M., G. V. Civille, \& B. T. Carr. 2016. Sensory Evaluation Techniques. 5th ed. CRC Press, Florida.

Mioč, B., V. Pavić, Z. Barać, Z. Prpić, \& I. Vnučec. 2007. Milk yield of some goat breeds in Croatia. Mljekarstvo. 57:67-77.

Mioč, B., Z. Prpić, I. Vnučec, Z. Barać, V. Sušić, D. Samaržija, \& V. Pavić. 2008. Factors affecting goat milk yield and composition. Mljekarstvo. 58:305-313.
Mishra, S., K. Kumari, \& A. Dubey. 2016. Body condition of dairy cattle: A review. RRJVS. 2:58-65.

National Bureau of Agricultural Commodity and Food Standards of Thailand. 2007. Halal Food (TAS 8400-2007). National Bureau of Agricultural Commodity and Food Standards, Ministry of Agriculture and Cooperatives, Bangkok, Thailand.

National Bureau of Agricultural Commodity and Food Standards of Thailand. 2013. Good Manufacturing Practices for Goat and Sheep Abattoir (TAS 9040-2013). National Bureau of Agricultural Commodity and Food Standards, Ministry of Agriculture and Cooperatives, Bangkok, Thailand.

Ostrowska, M., J. Jarczak, \& L. Zwierzchowski. 2015. Glucose transporters in cattle - A review. Anim. Sci. Pap Rep. 33:191-212.

Palka, K. 1999. Changes in intramuscular connective tissue and collagen solubility of bovine $\mathrm{m}$. semitendinosus during retorting. Meat Sci. 53:189-194. https://doi.org/10.1016/ S0309-1740(99)00047-9

Palka, K., \& H. Daun. 1999. Changes in texture, cooking losses, and myofibrillar structure of bovine $\mathrm{m}$. semitendinosus during heating. Meat Sci. 51:237-243. https://doi. org/10.1016/S0309-1740(98)00119-3

Seilsuth, S., J. H. Seo, H. S. Kong, \& G. J. Jeon. 2016. Microsatellite analysis of the genetic diversity and population structure in dairy goats in Thailand. Asian Australas. J. Anim. Sci. 29:327-332. https://doi.org/10.5713/ajas.15.0270

Suman, S. P., \& P. Joseph. 2013. Myoglobin chemistry and meat color. Annu. Rev. Food Sci. Tech. 4:79-99. https://doi. org/10.1146/annurev-food-030212-182623

Suman, S. P., P. Joseph, S. Li, L. Steinke, \& M. Fontaine. 2009. Primary structure of goat myoglobin. Meat Sci. 82:456-460. https://doi.org/10.1016/j.meatsci.2009.02.017

Supakorn, C., W. Pralomkarn, \& S. Tumwason. 2011. Estimation of additive, non additive gene effects and genetic parameters on pre-weaning growth traits in meat goats in southern Thailand. Walailak J. Sci. \& Tech. 8:41-50.

Wasiksiri, S., S. Sripongpun, A. Ratanaphan, \& P. Sookras. 2013. Survey to determine the presence of the $\mathrm{N}$-acetylglucosamine-6-sulfatase (G6S) gene mutation in Anglo-Nubian goats in Southern Thailand. Thai J. Vet. Med. 43:99-103.

Wattanachant, S., S. Benjakul, \& D. A. Ledward. 2004 Composition, color, and texture of Thai indigenous and broiler chicken muscles. Poult. Sci. 83:123-128. https://doi. org/10.1093/ps/83.1.123

Wattanachant, S., S. Benjakul, \& D. A. Ledward. 2005. Effect of heat treatment on changes in texture, structure and properties of Thai indigenous chicken muscle. Food Chem. 93:337-348. https://doi.org/10.1016/j.foodchem.2004.09.032

Węglarz, A. 2010. Meat quality defined based on $\mathrm{pH}$ and colour depending on cattle category and slaughter season. Czech J. Anim. Sci. 55:548-556.

Wondifraw, Z., B. M. Thombre, \& D. V. Bainwad. 2013. Effect of non-genetic factors on milk production of Holstein Frisian $x$ Deoni crossbred cows. Int. J. Livest. Prod. 4:106 112. https://doi.org/10.5897/IJLP2013.0173 